\title{
Halotolerant Bacillus sp. for Mannan Degradation Isolated from Mangrove Ecosystem at Hanura Beach Lampung
}

\author{
Sumardi* (D), Salman Farisi, Christina Nugroho Ekowati, \\ Achmad Arifiyanto 1 and Dwi Eka Rahmawati \\ Department of Biology, Faculty of Mathematics and Natural Sciences University of Lampung, Jl. Sumantri \\ Brojonegoro No. 1. Bandar Lampung, Lampung - 35145, Indonesia.
}

\begin{abstract}
Mannose and mannooligosaccharide acted as prebiotic that consumed by probiotic bacteria. Mannanase were the second most important enzymes for the hydrolysis of hemicelluloses, beside xylanase. The objective research was to obtain eminent strains of Bacillus sp. in mannan degradation which can potentially be a probiotic candidate. The study employed a completely randomized design using four concentration levels repeated six times. Halotolerant Bacteria were isolated from mangrove ecosystem at Hanura beach, Teluk Pandan, Pesawaran District in Lampung Province. They are grown on the sea water complete agar media. Mannan degradation isolates were then characterized to determine their character with a variety of tests, including resistance to $\mathrm{pH}$, salt, and metal ions, pathogenicity, and determination of mannanase production duration. Thirty strains are found to grow at 3-6\% salt content, and 9 of them have mannanolytic activity. They grow optimally at pH 7-10. Seven isolates were proven to be positively hydrolyzed blood agar in the pathogenicity test. The addition of Iron (III) Chloride increased the enzyme activity by $11.12 \%$ in IBK3 isolates at 96 hours of cultivation period which was $0.05 \mathrm{UmL}-1$. It acted as cofactors of enzymatic reactions. Strains Bacillus sp., were able to degrade mannan substrate. It quantified using Index of mannanolytic. Strain IBK3 has the highest index of mannanolytic activity as much as $\mathbf{1 0 . 7 4}$. Their ability to grow in salt media indicated that they were halotolerant. They were more likely to live at base rather than acid habitat. Only IBK3 and ID2K1 showed non-pathogenic isolates. Only $\mathrm{FeCl}_{3}$ addition has proven to rise up enzymatic activity.

Keywords: Characterization, Bacillus sp., Mannanase, Probiotic
\end{abstract}

*Correspondence: sumardi_bio@yahoo.co.id
(Received: March 21, 2020; accepted: June 12, 2020)
Citation: Sumardi, Farisi S, Ekowati CN, Arifiyanto A, Rahmawati DE. Halotolerant Bacillus sp. for Mannan Degradation Isolated
from Mangrove Ecosystem at Hanura Beach Lampung.J Pure App/ Microbiol. 2020;14(2):1237-1244. doi: 10.22207/JPAM.14.2.18
(C) The Author(s) 2020. Open Access. This article is distributed under the terms of the Creative Commons Attribution 4.0 International License which
permits unrestricted use, sharing, distribution, and reproduction in any medium, provided you give appropriate credit to the original author(s) and
the source, provide a link to the Creative Commons license, and indicate if changes were made. 


\section{INTRODUCTION}

Mangrove is a coastal intertidal wetland forest composed of halophytic tree and shrub species $^{1}$ and Indonesia has the largest mangrove forest in Southeast $\mathrm{Asia}^{2}$. The area of mangrove forests in Lampung Province was $17.110 \mathrm{ha}^{3}$. Hanura Village, Teluk Pandan District, Lampung was one of the many Lampung regions that had a mangrove ecosystem. The coastal waters of Hanura Village were mostly overgrown with mangrove forests and make them fertile because they get an accumulation of organic material from marine aquaculture activities in the form of sediment residues and mangrove leaf litter on the forest floor ${ }^{4}$. Organic materials from litter and dead mangrove stems are materials that decomposed by microorganisms. The microorganisms produce minerals that help maintain the fertility of the surrounding soil ${ }^{5}$. Structural analysis of the polysaccharides in the cell walls of dicotyledon is known to consist of cellulose, hemicellulose, and lignin $^{6}$.

Hemicellulose was the second polysaccharide which was very abundant in nature after cellulose. Hemicellulose had two main components, namely hetero-1.4- $\beta$-D-xilan and hetero-1.4- $\beta$-D-mannan ${ }^{7}$. The mannan component breaks down by mannanase into mannose and mannooligosaccharide. Mannose and mannooligosaccharide acted as prebiotic that consumed by probiotic bacteria. Mannanase enzyme activity has different levels depending on the source. This enzyme can be found from various sources including animals, plants, and microorganisms. In research, generally mannanase is taken from microorganism because it can be produced in large quantities and the isolation process is also easier ${ }^{8}$. Mannanase producing microorganisms was include Bacillus subtilis MAN-5119. Bacillus subtilis TJ-102 ${ }^{10}$, Bacillus pumilus $\mathrm{M} 27^{11}$ and Bacillus cereus $\mathrm{N} 1^{12}$. It would be very good if these bacteria are also probiotic. Probiotic bacteria produce enzymes that are able to break down complex compounds to be simple so they are ready to be used by fish feed ${ }^{13}$. The type of probiotic bacteria is influenced by the environment. Environmental factors such as $\mathrm{pH}$ condition and salinity where the bacteria are isolated greatly affect their ability to grow, develop and to carry out their functions as expected ${ }^{14}$. The ability of microorganisms to degrade mannan was very helpful in the field of aquaculture. It applied to the media for shrimp maintenance, water media, sub grade and feed. This study aims to obtain eminent strains of Bacillus sp. in mannan degradation which can potentially be a probiotic candidate for shrimp farming.

\section{MATERIAL AND METHODS Composition media}

Bacteria were cultured at Sea Water Complete (SWC) media with a composition of $0.5 \%$ locust bean gum, $0.5 \%$ peptone, $0.1 \%$ yeast extract, $0.3 \%$ glycerol, $1.5 \%$ agar, $25 \%$ aquades, and $75 \%$ sea water.

\section{Bacteria Selection for Mannanolytic activity}

Bacteria selection is conducted by qualitative method using agar plate assay. Bacterial collection were grown on SWC agar with the addition of $0.5 \%$ locust bean gum (LBG). After incubation for 24 hours, the colonies were stained with $1 \%$ congo red for 15 minutes. It washed again using $1 \mathrm{M} \mathrm{NaCl}$. Observations were made included mannanolytic index and bacterial staining. Selected colony with highest clear zones was tested using enzymatic assay with DNS method to determine the length of incubation time for enzyme production ${ }^{15}$.

\section{Salt tolerance test}

Mannanolytic isolates were further tested for their resistance to salt content. Bacteria were grown on SWC agar with the addition of salt as much as $0 \%, 3 \%$, and $6 \% \mathrm{NaCl}$. The size of the colony was observed after an incubation period of 24 hours at room temperature ${ }^{15}$.

\section{$\mathrm{pH}$ tolerance test}

Mannanolytic isolates were tested for their resistance to media $\mathrm{pH}$ stress. Bacteria were grown on SWC agar media with $\mathrm{pH} 4,7$, and 10 whereas $1 \mathrm{~N} \mathrm{HCl}$ and $1 \mathrm{~N} \mathrm{NaOH}$ were utilized respectively. After an incubation period of 24 hours at room temperature, growth and size of the colonies were observed and recorded ${ }^{15}$.

\section{Pathogenicity test}

Mannanolytic bacterial isolates were tested for their pathogenicity using sheepblood agar media. Observations were made after an incubation period of 24 hours at room 
temperature. Isolates that have the ability to hemolysis are shown by the formation of clear zones around the colony ${ }^{16}$.

\section{Metal susceptibility test}

Selected isolates that did not show any pathogenicity in the previous test were further tested in determining the mannanolytic index by growing on SWC media with the addition of metal substrates and ions to know mannanase acivity in metal ion present. The metals used are $\mathrm{Fe}, \mathrm{Pb}, \mathrm{Cu}$ and $\mathrm{Al}$ in the form of salt $\mathrm{FeCl}_{3}, \mathrm{PbCl}_{2}, \mathrm{CuCl}_{2}$, and $\mathrm{AlCl}_{3}{ }^{17}$.

\section{Mannanase enzyme production}

Starter was constructed using $50 \mathrm{~mL}$ liquid SWC media on $250 \mathrm{~mL}$ Erlenmeyer. The starter was incubated at room temperature for 48 hours using an orbital shaker. Furthermore, the starter was inoculated as much as $5 \mathrm{~mL}$ into $45 \mathrm{~mL}$ of liquid SWC media with the addition of $0.5 \%$ locust bean gum substrate and incubated in the shaker orbital $(120 \mathrm{rpm})^{15}$.

\section{Enzyme production}

Determination of the length of production time proposed by taking $5 \mathrm{~mL}$ of culture every 24 hours of incubation for 7 days. It centrifuged at $8500 \mathrm{rpm}$ for 15 minutes. Enzyme activity was determined using 3.5-dinitrosalicylic acid (DNS) method and the absorbance was read at a wavelength of $540 \mathrm{~nm}$. One unit (IU) of -mannanase activity was defined as the amount

Table 1. Bacteria Selection and Characterization

\begin{tabular}{|c|c|c|c|c|c|c|c|}
\hline \multirow[t]{2}{*}{ No. } & \multirow[t]{2}{*}{ Isolate } & \multirow[t]{2}{*}{ Gram } & \multicolumn{4}{|c|}{ Colony } & \multirow{2}{*}{$\begin{array}{l}\text { Mannanolytic } \\
\text { index }\end{array}$} \\
\hline & & & Shape & Margin & Elevation & Color & \\
\hline 1 & IAK1 & + & Circular & Filamentous & Raised & White & 5,35 \\
\hline 2 & IAK2 & + & Circular & Entire & Raised & White & 6,57 \\
\hline 3 & IAK3 & + & Irregular & Lobate & Raised & Yellow & - \\
\hline 4 & IAK4 & + & Circular & Filamentous & Raised & White & 5,47 \\
\hline 5 & $\mathrm{IA} 2 \mathrm{~K} 1$ & + & Circular & Entire & Raised & White & - \\
\hline 6 & $\mathrm{IA} 2 \mathrm{~K} 2$ & + & Circular & Entire & Flat & Pink & - \\
\hline 7 & $\mathrm{IA} 2 \mathrm{~K} 3$ & + & Circular & Filamentous & Flat & Clear & - \\
\hline 8 & IA2K4 & + & Circular & Entire & flat & Clear & - \\
\hline 9 & ILK3 & + & Circular & Entire & Raised & Orange & - \\
\hline 10 & ILK5 & + & Circular & Entire & Raised & Orange & - \\
\hline 11 & ILK6 & + & Circular & Undulate & Raised & Pink & - \\
\hline 12 & ILK9 & + & Irregular & Lobate & Flat & Clear & - \\
\hline 13 & IL2K5 & + & Circular & Entire & Flat & Clear & - \\
\hline 14 & IL2K8 & + & Irregular & Undulate & Flat & Clear & - \\
\hline 15 & IL2K9 & + & Circular & Entire & raised & White & - \\
\hline 16 & IKK1 & + & Circular & Undulate & Raised & White & 4,96 \\
\hline 17 & IKK3 & + & Circular & Entire & Raised & White & 2,61 \\
\hline 18 & IDK4 & + & Circular & Entire & Flat & White & - \\
\hline 19 & IDK6 & + & Circular & Entire & Raised & White & 9,14 \\
\hline 20 & ID2K1 & + & Circular & Filamentous & Flat & White & 10,64 \\
\hline 21 & ID2K2 & + & Circular & Undulate & Raised & White & 4,18 \\
\hline 22 & ID2K3 & + & Circular & Entire & Raised & Cream & - \\
\hline 23 & IBK1 & + & Circular & Filamentous & Flat & Clear & - \\
\hline 24 & IBK3 & + & Circular & Entire & Raised & Cream & 10,74 \\
\hline 25 & IPK3 & + & Circular & Irregular & Flat & Clear & - \\
\hline 26 & KA2K2 & + & Irregular & Undulate & Raised & Pink & - \\
\hline 27 & KA2K4 & + & Circular & Entire & Convex & Pink & - \\
\hline 28 & KBK2 & + & Irregular & Undulate & Raised & White & - \\
\hline 29 & KLK7 & + & Irregular & Undulate & Raised & White & - \\
\hline 30 & KL2K2 & + & Irregular & Lobate & Flat & White & - \\
\hline \multicolumn{2}{|c|}{ Number } & 30 & 30 & 30 & 30 & 30 & 30 \\
\hline
\end{tabular}


of protein producing $1 \mu \mathrm{mol} / \mathrm{L}$ of reducing sugar per minute (e.g., mannose) under standard conditions ${ }^{15}$.

\section{RESULTS}

\section{Bacteria Selection for Mannanolytic activity}

The selection results showed that there were 9 mananolytic isolates from a total of 30 isolates tested. These isolates were IAK1, IAK2, IAK4, IBK3, IDK6, ID2K1, ID2K2, IKK1, and IKK3. The IBK3 isolate gave the largest mananolytic index of 10.74 which was indicated by the clear zone formed around the colony (Table 1 ). Gram staining indicated that IBK3 isolates were Positive-bacteria in bacilli form.

\section{Salt tolerance test}

Probiotic microbes were able to grow and form colonies on bile salts ${ }^{18}$. The results showed that salt levels can affect bacterial growth. It is indicated by the size of the colony which varies in $0 \%, 3 \%$, and $6 \%$ salt content. Colony size of some bacteria tends to be larger in media with salt stress $0 \%$ and $3 \%$, whereas in media with salt content of $6 \%$ the size of the colony tended to be smaller (Fig. 1).

\section{pH tolerance test}

In testing the $\mathrm{pH}$ of the media showed that all isolates resistant to alkaline stress but not resistant to acids, this was indicated by the absence of appearance of bacteria that grow on media with a $\mathrm{pH}$ of 4 (Fig. 2).

\section{Pathogenicity test}

Isolates that show $\beta$-hemolysis or total hemolysis were IAK2, IKK1, IKK3, IDK6, ID2K2, while IKK1 and IKK3 were positive $\alpha$-hemolysis (partial). Isolates included in gamma hemolysis were IBK3 and ID2K1 (Fig. 3). Isolates with negative hemolysis $(\gamma)$ results will be used for further testing.

\section{Metal susceptibility test}

The presence of metal ions in the media acted as inhibitors or as cofactors of enzymatic reactions. The addition of $\mathrm{FeCl}_{3}$ metal as much as $20 \mathrm{mM}$ increased the mannanolytic index of IBK3 isolates which was 3.76 or $11.12 \%$ higher when compared to controls (Fig. 4).

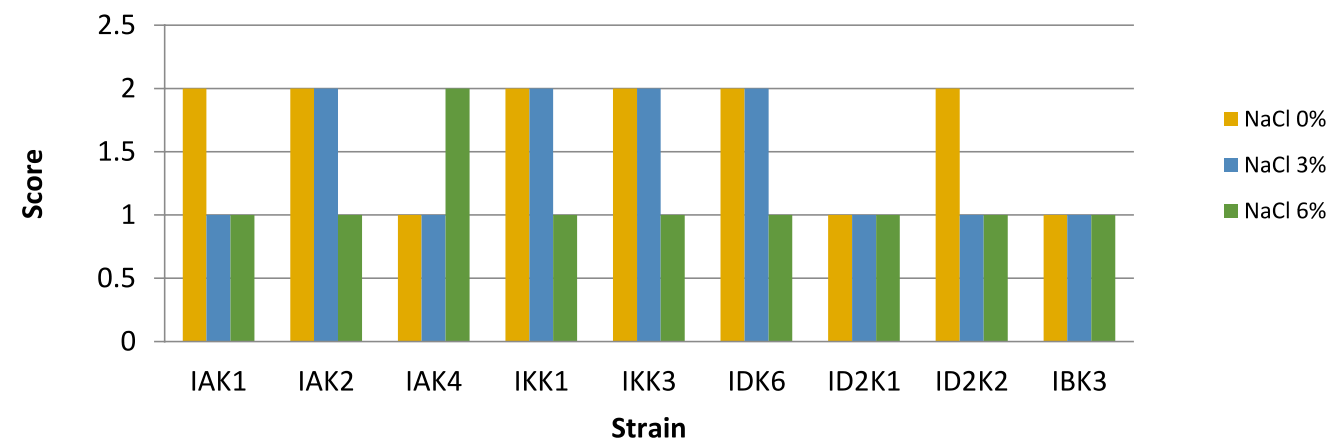

Fig. 1. Bacterial salt tolerant assay

Description: Score null = none growth, Score1 = small colony, Score 2 = Large colony,

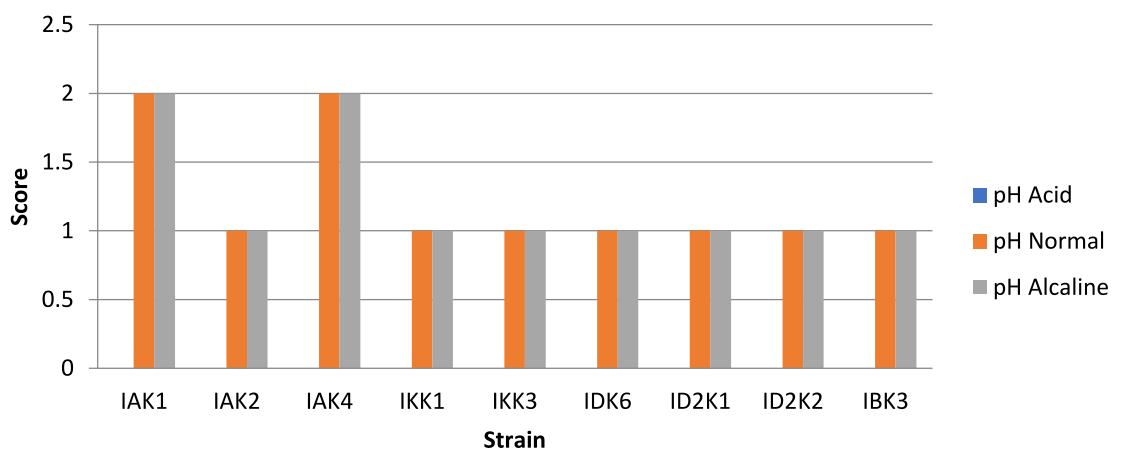

Fig. 2. Bacterial pH tolerant assay

Description: Score null = none growth, Score1 = small colony, Score 2 = Large colony 


\section{Enzyme production}

Mannanase enzymes are primary metabolites needed by bacteria to degrade carbon sources in the form of mannan contained in the locust bean gum substrate during bacterial growth. One unit of mannanase activity was defined as the amount of enzyme that released $1 \mu \cdot \mathrm{mol}^{-1}$ of reducing sugar per min under standard assay conditions ${ }^{22}$. The IBK3 isolate showed the highest enzyme activity at the production time of 96 hours, which was $0.05 \mathrm{UmL}^{-1}$ and continued to decline until 168 hours (Fig. 5).

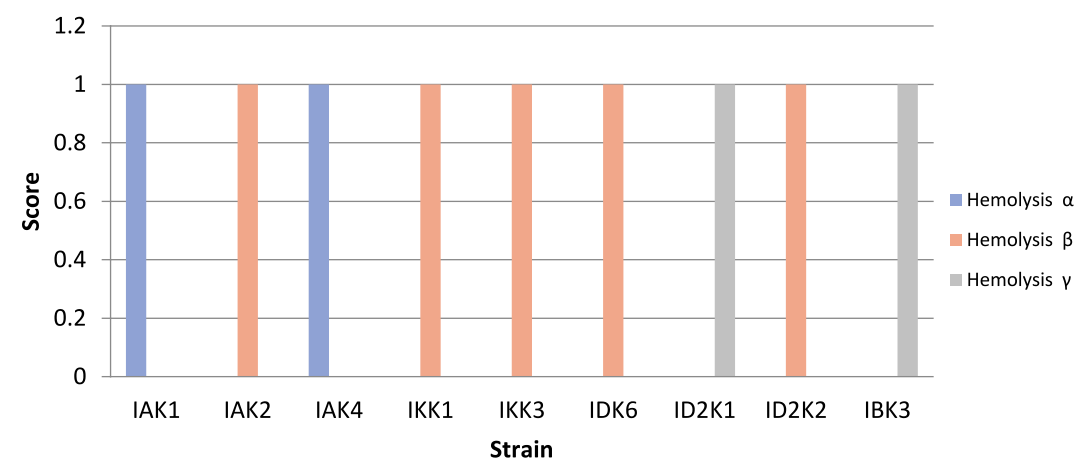

Fig. 3. Hemolytic test using blood agar assay

Description: Score null = negative reaction, Score1 = positive reaction

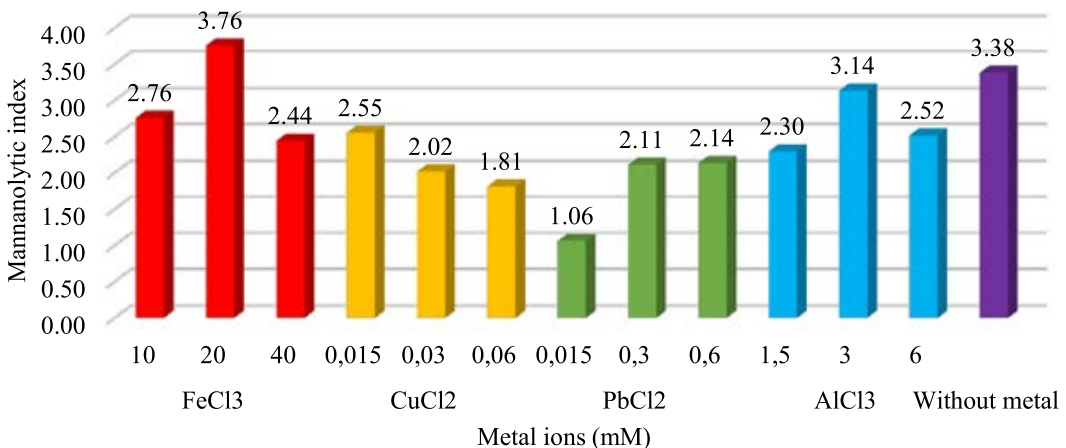

Fig. 4. Metal effect of $\mathrm{FeCl}_{3}(10 \mathrm{mM}, 20 \mathrm{mM}, 40 \mathrm{mM}), \mathrm{CuCl}_{2}(0.015 \mathrm{mM}, 0.03 \mathrm{mM}, 0.06 \mathrm{mM}), \mathrm{PbCl}_{2}(0.015 \mathrm{mM}, 0.03 \mathrm{mM}$, $0.06 \mathrm{mM})$, and $\mathrm{AlCl}_{3}(1.5 \mathrm{mM}, 3 \mathrm{mM}, 6 \mathrm{mM})$ to $\mathrm{IBK}_{3}$ isolate in producing mannanase enzyme.

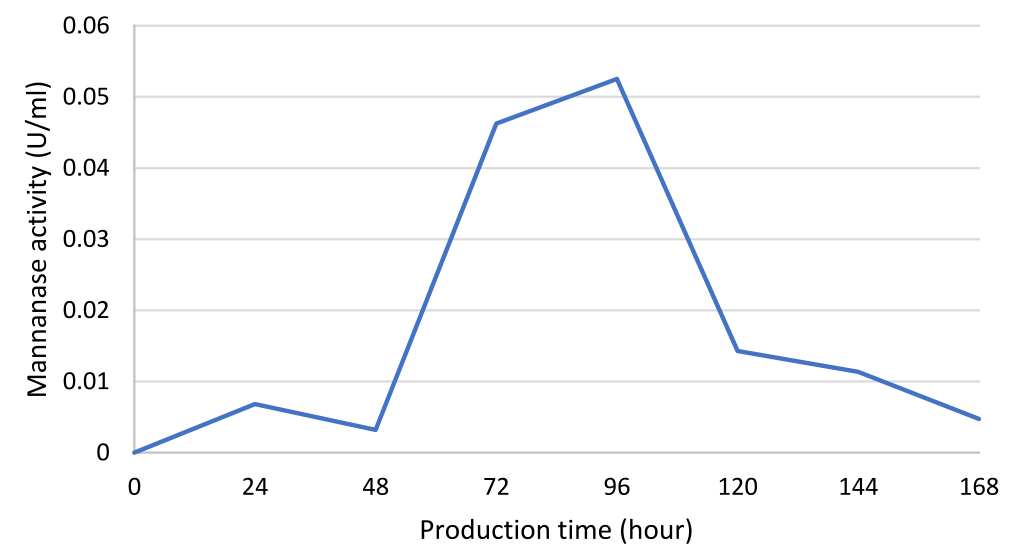

Fig. 5. IBK3 isolate mananase activity curve determined using DNS method and analyzed using spectrophotometer at $\lambda$ 540nm. 


\section{DISCUSSIONS}

Isolation of bacteria on SWC agar media with the addition of $0.5 \%$ locust bean gum (LBG) substrate showed the growth of mananolytic bacteria. The presence of mananolytic bacteria indicated by the presence of clear zones formed around bacterial colonies after staining with congo red and $\mathrm{NaCl}$. Congo red was bound into the B-1.4-D-manopiranosil bond and turned red to the media. LBG contained in the media had broken down by bacteria as a source of carbon in the process of metabolism. The breakdown produced mannose monosaccharides, reduced the binding of Congo red dye and consequently generated a clearing zone ${ }^{18}$.

The ability of isolates to grew in stress levels of salt influenced by the source of isolates obtained that our isolate was taken from estuary ecosystem. These results were almost the same as the research of ${ }^{17}$, they were show that marine bacteria can grow well at $2.5-5 \%$ salt content. Bacteria need nutrients to grow during the incubation period ${ }^{16}$. Nutrients were obtained from the surrounding environment media. The more acidic in media caused more hydrogen content in media. The presence of too many hydrogen ions in the media inhibited transport nutrients.

Bacteria that grow in the absence of salt and in the presence of high salt concentrations were known as halotolerant. Non-halotolerant which can grow in low salt concentration about $1 \% \mathrm{w} / \mathrm{v}$. Halotolerant bacteria, recovered from the composting process, were able to produce hydrolases, lipases, proteases, amylases, cellulases and biopolymers. Slightly tolerant as pseudomonads, enterobacteria, and vibrios, can survive in up to $2-8 \%$, moderately tolerant $18-20 \%$ and extremely tolerant microbes can grow over the whole range of salt concentrations from zero to saturation ${ }^{26}$. From these reason most of Bacillus that we obtained were halotolerant.

The halotolerant organisms maintain a low level of ionic concentrations to synthesize compatible solutes to balance the osmotic level inside the cytoplasm with the outer medium. These maintenance mechanisms of the internal environment and the properties of the cytoplasmic membrane help them to adapt to changes in the saline environment as salt lakes, saline soils, and salted food products ${ }^{27}$.
Probiotic agents must not be pathogenic and had proven to have health effects ${ }^{18}$. The observation of hemolysis test gave of various results. Hemolysis divided into 3 was namely alpha, beta, and gamma hemolysis. Beta hemolysis was a complete lysis of red blood cells, it caused around the colony turn to clear area. Alpha hemolysis was partial hemolysis while gamma hemolysis was no hemolysis ${ }^{19}$. Toxicity tests were important not only to discard those few species of some Bacillus genera, such as B. cereus and B. anthracis. Consequently, these two $\gamma$ hemolytic strains (IBK3 and ID2K1) were the most promising probiotic candidates from all 30 isolated Bacillus because they were not pathogenic or able of producing toxic substances that may harm fish, or shellfish. IBK3 was selected to optimize in the enzyme production due to had the highest mannanolytic index.

Metal ions were optimized through mannan degrading-enzyme activity. It conducted to understand which metal played as cofactor or even inhibitor in mannan degradation. Mannanase activity of Bacillus subtilis increased with the addition of $\mathrm{Fe}^{3+}$ metal ions ${ }^{20}$. Unfortunately it is unable tolerated $\mathrm{Cu}_{2}{ }^{+}$more than $0.015 \mathrm{mM}$, because ${ }^{7}$ confirmed that $\mathrm{Cu}^{2+}$ acted as an inhibitor of the mannanase enzyme from Geobacillus stearothermophillus L-07. It tolerated lead $\left(\mathrm{Pb}^{2+}\right)$ less than $0.06 \mathrm{mM}$. It accumulated $\mathrm{Al}^{3+}$ in maximum no more than $3 \mathrm{mM}$. Beside that metal ions played as inhibitors when it bound to the active side of the enzyme so that the enzyme became ineffective in binding the substrate (Fig. 1). These results were in accordance with the research ${ }^{21}$ which showed the highest activity of the mannanase used Bacillus cereus in the production time of 88-96 hours. It ${ }^{7}$ showed the highest activity of the enzyme mannanase isolate Geobacillus stearothermophillus $\mathrm{L}-07$ at the time of production of 36 hours with 3.1 U.mg-1activity.

\section{CONCLUSION}

Strains Bacillus sp., were able to degrade mannan substrate. It quantified using Index of mannanolytic. Strain IBK3 has the highest index of mannanolytic activity as much as 10.74 . Their ability to grow in salt media from 3- $6 \%$ salt content indicated that they were slightly halotolerant. They were more likely live at base 
rather than acid habitat. Only IBK3 and ID2K1 showed non-pathogenic isolates. Only $\mathrm{FeCl}_{3}$ addition has proven to rise up enzymatic activity.

\section{ACKNOWLEDGEMENTS}

We would like to express our grateful thanks to Ms. Oni Mastuti for her assistance with the $L A B$ experiments.

\section{CONFLICT OF INTEREST}

The authors declare that there is no conflict of interest.

\section{AUTHORS' CONTRIBUTION}

$S$ and SF designed the experiments. CNE performed the experiments. AA and DER analyzed the data and wrote the manuscript. S, SF and CNE read and approved the manuscript.

\section{FUNDING}

None.

\section{ETHICS STATEMENT}

This article does not contain any studies with human participants or animals performed by any of the authors.

\section{DATA AVAILABILITY}

The datasets are available from the corresponding author on reasonable request.

\section{REFERENCES}

1. Friess Daniel A. Current Biology Magazine Ed 26. R739-R755, August 22. CellPress-Elsevier Ltd, 2016.

2. Choong Elvin T, Wirakusumah, R Sambas, Achmadi Suminar S. Mangrove forest resources in Indonesia. Forest Ecology and Management. 1990;33-34:4557. https://doi.org/10.1016/0378-1127(90)90183-C

3. Badan Pusat Statistik (BPS). Luas dan Kondisi Hutan Mangrove Menurut Provinsi Lampung. https:// lampung.bps.go.id/dynamictable/2017/08/23/510/ luas-dan-kondisi-hutan-mangrove-menurutprovinsilampung-.html.

4. Siegers WH. Kondisi Ekologi Makrobentos pada EkosistemHutan Mangrove dan Laut Desa Hanura Kecamatan Padang CerminProvinsi Lampung. The Journal of Fisheries Development. 2014;1(1):27-43.

5. Asna PM, Nugraheni FSA, Hastuti US. Isolasi dan Karakterisasi Bakteri Amilolitikdari Tanah Mangrove di Margomulyo Balikpapan, Kalimantan Timur. Prosiding Seminar Nasional III Tahun 2017. 2017. [Indonesian]

6. Dhawan S, Kaur J. Microbial Mannanases: An Overview of Production and Applications. Critical Reviews in Biotechnology. 2007;27:197-216. https://doi. org/10.1080/07388550701775919

7. Sumardi. Optimasi Produksi Enzim $\beta$-mannanase Ekstraseluler dari Bakteri Geobacillus stearothermophilus L-07. Jurnal Sains Tek. 2005;11(2):66-71.

8. Seftiono H. Penentuan Aktivitas Enzim Mannanase dari Berbagai Mikoorganisme di Indonesia dan Perannya dalam Bidang Pangan: Kajian Pustaka. Jurnal Agrointek. 2017;11(1):14-20. https://doi. org/10.21107/agrointek.v11i1.2939

9. Utami DR, Sutrisno A, Kusnadi J. Isolation, Purification and Characterization of Mannanase from Bacillus subtilis MAN-511. International Journal of Science Technology \& Engineering (IJSTE). 2016;2(11):83-87.

10. Wang $M$, You S, Zhang $S$. et al. Purification, Characterization and Production of $\beta$-mannanase from Bacillus subtilis TJ-102 and its application in glucomannooligosaccharides Preparation. Eur Food Res Technol. 2013;237:399-408. https://doi.org/10.1007/ s00217-013-2002-1

11. Adiguzel A, Nadaroglu $H$, Adiguzel G. Purification and Characterization of $\beta$-mannanase from Bacillus pumilus M27 and its applications in some fruit juices. Journal Food Sci Technol. 2015;52:5292-5298. https:// doi.org/10.1007/s13197-014-1609-y

12. El-Sharounya EE, El-Toukhyb NM, El-Sersyc NA, El-Gayara AA. Optimization and Purification of Mannanase Produced by an Alkaliphilic-termotolerant Bacillus cereus N1 isolated from Bani Salama Lake in Wadi El-Natron. Biotechnol Equip. 2015;29:315-323. https://doi.org/10.1080/13102818.2014.995932

13. Ichim TE, Patel AN, Shafer KA. Experimental support for the effects of a probiotic/digestive enzyme supplement on serum cholesterol concentrations and the intestinal microbiome. J Transl Med. 2016;14:184. https://doi. org/10.1186/s12967-016-0945-2

14. Muliani, Nurbaya, Madeali MI. Teknik Aplikasi Bakteri Probiotik pada Pemeliharaan Udang Windu (Panaeus monodon) di Laboratorium. JurnalRis. Akuakultur. 2011;6(1):81-92. https://doi.org/10.15578/ jra.6.1.2011.81-92

15. Sumardi, Suwanto A, Thenawidjaja M, Purwadaria T. Isolation and Characterization of Mannanolytic Thermophilic Bacteria from Palm Oil Shell and their Mannanase Enzyme Production Properties. Biotropia. 2005;25:1-10. https://doi.org/10.11598/ btb.2005.0.25.211

16. Arifiyanto A, Surtiningsih T, Ni'matuzahroh, Fatimah Agustina D, Alami NH. Antimicrobial activity of biosurfactants produced by actinomycetes isolated from rhizosphere of Sidoarjo mud region. Biocatalysis and Agricultural Biotechnology. 2020;24:1-7. https:// doi.org/10.1016/j.bcab.2020.101513

17. Arifiyanto A, Apriyanti FD, Purwaningsih $P$, et al. Lead $(\mathrm{Pb})$ bioaccumulation; genera Bacillus isolate S1 and SS19 as a case study. AIP Conference Proceedings. 2017;1854(1):020003. https://doi. org/10.1063/1.4985394

18. Kim S, Lee MH, Lee ES, Nam YD, Seo DH. Characterization of mannanase from Bacillus sp., a novel Codium fragile cell wall-degrading bacterium. Food Science and Biotechnology. 2017;27(1):115-122. https://doi. 
org/10.1007/s10068-017-0210-3

19. Sunaryanto $\mathrm{R}$, Martius E, dan Marwoto $B$. Uji Kemampuan Lactobacillus caseisebagai Agensia Probiotik. Jurnal Bioteknologi \& Biosains Indonesia. 2014;1(1):9-14. https://doi.org/10.29122/jbbi. v1i1.546

20. Irianto A, Hendrati PM. Biodiversity of aerobic heterotrophic bacteria from Baron beach, Gunung Kidul, Yogyakarta. BIODIVERSITAS. 2003;4(2):80-82. https://doi.org/10.13057/biodiv/d040202

21. Yulinery T, Yulianto E, Nurhidayat N. Uji Fisiologis Probiotik Lactobacillus sp. Mar 8 yang Telah Dienkapsulasidengan Menggunakan Spray Dryer untuk Menurunkan Kolesterol. Jurnal Biodiversitas. 2006;7(2):118-122. https://doi.org/10.13057/biodiv/ d070205

22. Hamtini Isolasi dan Karakterisasi Bacillus sp. dariikanLele (Clarias sp.) serta Potensinyasebagai Probiotik. [Thesis]. Institut Pertanian Bogor. Bogor. 2014. http://repository.ipb.ac.id/handle/123456789/70884. [Indonesian]

23. Jiang Z, Wei Y, Li D, Li L, Chai P, Kusakabe I. Highlevel production purification and characterization of a thermostable $\beta$-mannanase from the newly isolated Bacillus subtilis WY-34. Carbohydr Polym. 2006;66:88-96. https://doi.org/10.1016/j. carbpol.2006.02.030

24. Mairizal, Marlida, Y, Mirzah, Manin F. Isolation and Characterization of Mannanase-producing Bacillus cereus Isolated from the Hindgut of Termites. Pak J Nutr. 2018;17(3):116-123. https://doi.org/10.3923/ pjn.2018.116.123

25. Xia W, Lu H, Xia M. et al. A Novel Glycoside Hydrolase Family 113 Endo--1,4-Mannanase from Alicyclobacillus sp. Strain A4 and Insight into the Substrate Recognition and Catalytic Mechanism of This Family. Appl Environ Microbiol. 2016;82(9):2718-2727. https://doi. org/10.1128/AEM.04071-15

26. Rahman SS, Siddique R, Tabassum N. Isolation and identification of halotolerant soil bacteria from coastal Patenga area. BMC Res Notes. 2017;10:531. PMID: 29084602. https://doi.org/10.1186/s13104-017-28557

27. Roberts MF. Organic compatible solutes of halotolerant and halophilic microorganisms. Saline Syst. 2005;1(1):5. https://doi.org/10.1186/1746-1448-1-5 